\title{
Analysis on Technical Efficiency of Regional Listed Agricultural Companies of Economic Nature in China Based on DEA-Tobit Two-Step Method
}

\author{
Youyang You \\ International Business School \\ Yunnan University of Finance and Economics \\ Kunming, China \\ 85621767@qq.com
}

\begin{abstract}
In this paper, the efficiency of regional listed agricultural companies of economic nature in China is analyzed based on financial data of 39 regional agricultural companies of economic nature listed at Shanghai and Shenzhen Stock Markets (A-share) in 2015 in combination with both constant returns to scale DEA model (CRS-DEA) and variable returns to scale DEA model (VRS-DEA). And on the basis of DEA analysis, Tobit model is applied to analyze the effects of pure technical efficiency and scale efficiency on overall efficiency; then, financial considerations (latest guarantee amount, financial status indicators, latest loan amount, total equity) influencing operating efficiency of regional agricultural companies of economic nature are analyzed and dummy variables are introduced to analyze technical efficiency of forestry, animal husbandry, fishery and mixed industry.
\end{abstract}

The empirical results show that pure technical efficiency and scale efficiency together lead to low efficiency of regional listed agricultural companies of economic nature in China, while the weakness of regional agriculture of economic nature itself, deficient ability to avoid risk as well as blindly following of diversified strategy are major factors influencing pure technical efficiency and scale efficiency.

Keywords-DEA model; Tobit model; regional listed agricultural companies of economic nature; technical efficiency Introduction

\section{INTRODUCTION}

By the end of 2015, 45 regional listed agricultural companies of economic nature had come into existence in China, accounting for $2.01 \%$ of the total number of listed companies (A-share) at that time. China's regional listed agricultural companies of economic nature are inadequate in quantity, small in scale, weak in competence of risk resistance and severe in non-agricultural expansion. Therefore, analyzing the operating efficiency of regional listed agricultural companies of economic nature helps to improve the efficiency of the companies as a whole. DEA model can be used to calculate the relative efficiency of decision making units in a variety of inputs and outputs system, but it is not able to find the factors that affect the efficiency. Therefore, in order to solve the problem of the interception of the efficiency distribution while using the DEA model, the Tobit model is very effective.

\section{SELECTION OF DMUS}

In accordance with the definition of the Guidance for Industry Classification of Listed Companies issued by China Securities Regulatory Commission in 2005, regional listed agricultural companies of economic nature refer to agricultural, forestry, animal husbandry and fishery companies listed in the A-share market except food industry and beverage industry. To reduce the impact of abnormal values on analysis results, this paper excludes 6 regional listed agricultural companies of economic nature fined by the securities regulatory authorities and with volatile financial indicators and some negative indicators, in the end, 39 regional listed agricultural companies of economic nature in Shanghai and Shenzhen Stock Exchanges (A-share) are taken as DMU with their operating efficiency being analyzed. To ensure the accuracy and objectivity of the results, according to new Accounting Standards for Business Enterprises, all listed companies and their financial indicators are taken from Star Securities website in a unified way.

\section{DETERMINATION OF INDICATORS}

One important principle of DEA model is that each DMU has the same input and output in the same perspective[6]. In this paper, different kinds of regional listed agricultural companies of economic nature are regarded as homogeneous institutions which make profits through the use of assets. Thus, the input indicators only involve assets and costs, the output indicators only involve the earning capacity.

The selection of input and output indicators directly relates to the accuracy of DEA model for measuring the operating efficiency of regional listed agricultural companies of economic nature. Therefore, the indicators should not only consider the operation, management and capital situation of the companies, but also consider the availability of data. In this paper, the following indicators are chosen based on the research results of Luo Huawei (2012) [6], Veronika Fenyves (2015) et al [7]: total assets, which are wealth owned by the 
companies and may bring future profits to the companies, the performance of the companies in the use of assets is directly related to the benefit of the companies; Total operating costs: clear development strategy and good business income are important features to measure whether regional agricultural listed companies of economy nature have development potential. While relative to main business income, total operating costs are input variables, representing the efficiency of a regional listed agricultural company of economic nature; three major costs: in this study, the sum of management, financial and marketing costs represents three major costs. Output indicator: total operating income, this indicator reflects the profitability of main business of a regional listed agricultural company of economic nature, the higher this value, the greater the company's development potential, which is the main power for the development of the company; Total profit: this indicator includes not only the company's income on major businesses, but also the company's income resulted from investment and the use of financing planning, which can fully reflect the company's profitability.

Based on the above analysis, this paper conducts descriptive statistics for sample input and output indicators, the results are shown in Table 1.

TABLE I. THE RESULTS OF DESCRIPTIVE STATISTICS FOR SAMPLE INPUT AND OUTPUT INDICATORS (UNIT: 10000 YUAN)

\begin{tabular}{lllc}
\hline Statistics Indicator & Maximum & Minimum & Average value \\
\hline Total operating income & 133047.2 & 754.9 & 19415.8 \\
Total profit & 76902.8 & 442.7 & 16961.8 \\
Total assets & 1800247.2 & 904.9 & 305596.4 \\
Total operating costs & 1088561.4 & 3305.3 & 155862.8 \\
Three major costs & 2888808.6 & 20665.3 & 461860.5 \\
\hline
\end{tabular}

\section{DEA Results}

The efficiency and returns to scale of Chinese regional listed agricultural companies of economic nature in 2015 are studied from the angle of input according to the formula, the calculation results are shown in Table 2.

TABle II. The Calculation Results of Chinese Regional ECONOMic Listed Agricultural COMPANiES IN 2015

\begin{tabular}{|c|c|c|c|c|c|c|c|c|c|}
\hline Item & CRS & VRS & VRS & $\lambda$ & Item & CRS & VRS & VRS & $\lambda$ \\
\hline Xiang $L i$ & 0.76 & 1 & 0.76 & + & $\mathrm{Da} H u$ & 0.73 & 0.73 & 0.99 & + \\
\hline Feng Le & 0.93 & 0.97 & 0.96 & - & Ming $\mathrm{He}$ & 0.89 & 0.91 & 0.99 & - \\
\hline Guo Tou & 0.81 & 0.82 & 0.99 & - & Ji Lin & 0.77 & 0.79 & 0.97 & - \\
\hline Luo Niu & 0.65 & 0.65 & 0.99 & 0 & Sheng Nong & 0.92 & 1 & 0.92 & - \\
\hline Da Nong Hua & 0.85 & 0.85 & 1 & 0 & Ya Sheng & 0.74 & 0.78 & 0.95 & - \\
\hline Zhong Shui & 0.67 & 0.69 & 0.98 & + & Hua Ying & 0.85 & 0.87 & 0.98 & - \\
\hline Hai Nan & 0.95 & 1 & 0.95 & - & Kai Chuang & 0.70 & 0.70 & 0.99 & + \\
\hline Shun Xin & 0.91 & 1 & 0.91 & - & Yi Qiao & 1 & 1 & 1 & 0 \\
\hline FangPing & 0.89 & 0.90 & 0.99 & + & Tian Shan & 0.95 & 1 & 0.95 & + \\
\hline Long Ping & 0.84 & 0.87 & 0.97 & - & Yi sheng & 1 & 1 & 1 & 0 \\
\hline XinWu Feng & 1 & 1 & 1 & 0 & Shen Nong & 0.77 & 0.78 & 0.98 & + \\
\hline Deng Hai & 1 & 1 & 1 & 0 & Chu Ying & 1 & 1 & 1 & 0 \\
\hline Dun Huang & 0.81 & 0.87 & 0.93 & - & Lang Yuan & 0.88 & 0.9 & 0.98 & + \\
\hline Zhang Zi Dao & 0.96 & 1 & 0.96 & - & Da Kang & 0.99 & 1 & 0.99 & + \\
\hline Zhong Nong & 1 & 1 & 1 & 0 & Gu Mu Zhen & 0.79 & 0.82 & 0.96 & + \\
\hline Dong Fang & 0.73 & 0.74 & 0.99 & + & Quan Ying & 0.72 & 0.74 & 0.97 & + \\
\hline Hao Dang Jia & 0.87 & 0.87 & 0.99 & - & $X i B u$ & 0.83 & 0.94 & 0.89 & + \\
\hline Fu Cheng & 0.88 & 0.89 & 0.99 & + & Guo Lian & 0.81 & 0.82 & 0.99 & - \\
\hline Zhong Chang & 1 & 1 & 1 & 0 & Zhong $F u$ & 0.68 & 0.69 & 0.99 & + \\
\hline Bei Da Huang & 0.86 & 1 & 0.86 & - & Ping Jun Zhi & 0.86 & 0.89 & 0.97 & \\
\hline
\end{tabular}




\section{A. Analysis of overall efficiency}

The mean of overall efficiency of China's regional listed agricultural companies of economic nature in 2015 is 0.86 , the minimum overall efficiency value is 0.65 . It can be divided into four categories according to overall efficiency.

First, the overall efficiency of seven companies reaches 1, indicating that such regional listed agricultural companies of economic nature have quite reasonable input and output of resources, effective scale \& technology and constant returns to scale, the industry completely achieves all benefits brought about by scale efficiency and technical efficiency, and there is no loss of efficiency.

Second, overall efficiency is less than 1 and scale efficiency is 1, pure technical efficiency equals to combined efficiency, indicating that such regional listed agricultural companies of economic nature have modest development, the proportion of increase in output is equal to the proportion of increase in all kinds of production factors.

Third, overall efficiency is less than 1, pure technical efficiency is 1 , scale efficiency equals to overall efficiency. It is mainly because of inappropriate industrial investment scale leading to low overall efficiency, the overall efficiency of such regional listed agricultural companies of economic nature is invalid. Among them, some presents a trend of increasing returns to scale, while the development of the rest presents a trend of decreasing returns to scale.

Fourth, three indicator values of overall efficiency are all below average, indicating the overall efficiency of such regional listed agricultural companies of economic nature is invalid, this is caused by low resource utilization in conjunction with inappropriate input and output.

\section{B. Analysis of pure technical efficiency}

In this study, the mean of sample pure technical efficiency is 0.89 , among them, the pure technical efficiency value of 19 companies is greater than or equals to the mean, however, the overall level is still low. The pure technical efficiency value of 15 companies (accounting for $38.46 \%$ of total sample regional listed agricultural companies of economic nature) is 1 , which is at the frontier of pure technical efficiency, compared with other 24 companies; these 15 companies show greater advantage in corporate governance and internal supervision, etc. To further increase the company's production, technology should be improved to change production function; in addition, taking measures eliminating efficiency limiting factors can also realize the growth of production.

\section{Analysis of scale efficiency}

In this study, 25 regional listed agricultural companies of economic nature are above the mean of 0.97 , indicating that the overall scale efficiency of such companies is relatively high. However, the SC of only 9 companies (accounting for $20.1 \%$ of total sample) is 1 , indicating that China's regional listed agricultural companies of economic nature still have greater potential in terms of moderate scale management. Meanwhile, some companies adopt extensive mode of production and management, leading to low production efficiency. For example, 15 companies are in the state of decreasing $\lambda$, indicating their input redundancy, and 15 companies are in the state of increasing $\lambda$, indicating their low level of inputs affecting the exertion of scale efficiency.

\section{REgRESSION ANALYSES WITH TOBIT MODEL}

First, this paper analyzes the impact of pure technical efficiency and scale efficiency on overall technical efficiency and the degree of contribution, so that the specific factors that lead to the low overall efficiency can be found out, thereby finding ways to solve these factors. And then, it analyzes the impact of the company's financial situation on the efficiency with efficiency value as dependent variable. The indicators reflecting the company's financial situation mainly include latest guarantee amount, financial status indicator, latest loan amount and total equity; To distinguish the impacts of different main categories of regional listed agricultural companies of economic nature, this paper adds dummy variables such as forestry, animal husbandry, fishery and mixed industry (auto parts and raw materials, pharmaceuticals, biotechnology and life science, etc.), the results are shown in Table 3.

TABLE III. REGRESSION ANALYSIS RESULTS WITH TOBIT MODEL FOR REGIONAL ECONOMIC AGRICULTURE LISTED COMPANY EFFICIENCY

\begin{tabular}{|c|c|c|c|c|c|}
\hline crs & Coefficient & Variables & crs & $\mathbf{v r}$ & sc \\
\hline$v r$ & $0.99 * * *$ & latest loan amount and total equity & $1.96 \mathrm{E}-11$ & $6.49 \mathrm{E}-10 * *$ & $-3.35 \mathrm{E}-11^{* *}$ \\
\hline$s c$ & $0.99 * * *$ & financial status indicator & $-1.33 \mathrm{E}-03$ & $-4.40 \mathrm{E}-03$ & $5.51 \mathrm{E}-04$ \\
\hline \multirow[t]{7}{*}{ Constant } & $-0.98 * * *$ & latest loan amount & $2.40 \mathrm{E}-12$ & $3.89 \mathrm{E}-11$ & $-1.85 \mathrm{E}-11^{* * *}$ \\
\hline & & total equity & $-2.83 \mathrm{E}-12$ & $1.66 \mathrm{E}-11$ & $-8.10 \mathrm{E}-12^{*}$ \\
\hline & & forestry & $-1.37 \mathrm{E}-01 * * *$ & $-2.09 \mathrm{E}-01 * * *$ & $4.01 \mathrm{E}-02$ \\
\hline & & animal husbandry & $1.40 \mathrm{E}-02$ & $-4.50 \mathrm{E}-02$ & $5.17 \mathrm{E}-02 *$ \\
\hline & & fishery & $-8.25 \mathrm{E}-02$ & $-1.34 \mathrm{E}-01^{*}$ & 4.09E-02 \\
\hline & & mixed industry & $6.35 \mathrm{E}-02$ & $3.59 \mathrm{E}-02$ & $4.51 \mathrm{E}-02$ \\
\hline & & Constant & $8.65 \mathrm{E}-01 * * *$ & $8.86 \mathrm{E}-01 * * *$ & $9.50 \mathrm{E}-01 * * *$ \\
\hline
\end{tabular}

In Table 3, the regression coefficient of pure technical efficiency and scale efficiency to overall efficiency is positive and statistically significant. Meanwhile, forestry, animal husbandry, fishery and mixed industry are dummy variables, while latest guarantee amount, financial status indicators, latest loan amount and total equity are continuous variables. 
The impact of latest guarantee amount on pure technical efficiency is positive, but its impact on scale efficiency is negative, indicating that the company has sufficient liquid assets, which has significant positive impact on pure technical efficiency. However, higher liquidity may not fully applied to the company's production and operation activities, thus having negative impact on scale efficiency. Latest loan amount and total equity have no significant effect on overall technical efficiency and pure technical efficiency, but its effect on scale efficiency is negative, that is, under the condition of larger loan amount, it reflects that the company has larger input in production and management activities, however, since such input comes from borrowing, it indicates that the increase in loan cannot bring the increase in scale efficiency, it may be that there are natural risk and market risk in the investment, while regional listed agricultural companies of economic nature have deficient ability to avoid risk. Meanwhile, it shows that the companies with larger total equity (total corporate capital) have low scale efficiency yet. It may be that while successfully financing for the company, larger total equity also brings larger division of equity, however, regional listed agricultural companies of economic nature are not yet mature in terms of this mode of operation, thus leading to relatively low scale efficiency, indicating that the development of regional listed agricultural companies of economic nature in China is not yet perfect, during this period, regional listed agricultural companies of economic nature shall reduce the input in loan fund in order to increase larger division of scale efficiency and equity.

\section{CONCLUSIONS AND SUGGESTIONS}

It is indicated through evaluating and analyzing the operating efficiency of China's 39 regional listed agricultural companies of economic nature in 2015:

(1) The overall efficiency value of China's regional listed agricultural companies of economic nature is relatively low. The operating activities of only a handful of such companies are in the state of constant returns to scale. The number of the companies with increasing scale and those with decreasing scale hold the line.

(2) It is shown by the regression results of Tobit model for efficiency affecting factors of regional listed agricultural companies that for regional listed agricultural companies, the degree of contribution of pure technical efficiency to overall efficiency is similar to that of scale efficiency to overall efficiency; the weakness of regional agriculture of economic nature itself, deficient ability to avoid risk as well as blindly following of diversified strategy are main reasons affecting pure technical efficiency and scale efficiency.

From the above conclusions, the following suggestions are put forward:

(1) Pure technical efficiency and scale efficiency are important factors restricting the overall efficiency of regional listed agricultural companies of economic nature, in the future, the improvement shall be made in operation and management, optimized combination of resources as well as technology innovation.

(2) The companies with increasing returns to scale shall increase investment and expand the scale of production so as to improve their operating efficiency; while the companies with decreasing returns to scale shall take moderate scale management as the goal, decrease excessive input items, optimize the combination of various inputs, improve the utilization efficiency of all inputs, reduce production and operation costs and improve the operating efficiency. Whether the companies with increasing scale or those with decreasing scale, when adjusting scale, they should avoid and give up the path of extensive growth.

(3) Deep processing enterprises with science and technology as the guide will be the inevitable choice for regional listed agricultural companies of economic nature in the future. Therefore, it is suggested to actively introduce high and new technology to transform traditional agriculture, optimize the structure of agricultural products, improve the quality of agricultural products, broaden agricultural industry chain and strengthen deep processing ability. Meanwhile, stable technical cooperation relationship with scientific research institutions shall be established to constantly strengthen the enterprises' ability in technological innovation.

\section{ACKNOWLEDGMENT}

This paper is sponsored by Yunnan science and Technology Department application of basic research projectYouth project No.2014FD024Equations. Some of the data in this paper were from Dr. Xiao Yugu in Renmin University of China, Dr. Zheng Sujin in Central University of Finance and Economics. Therefore, thanks for the information and helps from these professors.

\section{REFERENCES}

[1] R. Färe, S. Grosskopf, and C.A.K. Lovell, "Production Frontier," London: Cambridge University Press, 1994.

[2] Hsuan Shih Lee, W.C. Ching, Z. Joe, "Super-efficiency DEA in the presence of infeasibility," European Journal of Operational Research , 2011, vol. 212, pp. 141-147.

[3] R. Färe, S. Grosskopf, "DEA, directional distance functions and positive, affine data transformation," Omega, vol. 4, pp. 28-30, January 2013,

[4] J.M. Woodridge, "Introductory Economics: A Modern Approach," 3rd Ed, Beijing: China Renmin University Press, 2007.

[5] Z.H. Sheng, and Q. Zhu, G.M. Wu, "Theory, method and application of DEA,” M. Beijing: Science Press, 1979.

[6] H.W. Luo, "Performance Evaluation of China's Agricultural Listed Companies Based on DEA Model," Asian Agricultural Research, 2012, pp. 1-6.

[7] V. Fenyves, T. Tarnóczi, and K Zsidó, "Financial Performance Evaluation of Agricultural Enterprises with DEA Method," Procedia Economics and Finance, vol. 32, 2015, pp. 423-431. 